\title{
RESIDENTS' ATTITUDES TOWARDS TOURISM IMPACTS IN RURAL AREA
}

\author{
Ivana Pavlić \\ Barbara Puh \\ Ljubica Mišković
}

https://doi.org/10.20867/tosee.05.19

\begin{abstract}
Purpose - The main purpose of this paper is to research local residents' attitudes living in rural areas towards tourism development regarding economic, socio-cultural and environmental tourism impacts and to analyse possible relationships between residents' attitudes related to tourism impacts and their socio-demographic characteristics.

Methodology - The research was made in a period from June 2017 to October 2017 on a stratified sample of 593 residents in rural areas around Dubrovnik. For data analysis MANOVA was used for examining the relationship between respondents' characteristics and attitudes towards tourism impacts. Further analysis included t-tests and ANOVA for individual statements.

Findings - The findings indicate the differences in residents' attitudes towards tourism impacts regarding age, education, employment status, personal monthly income and job relation to tourism. Contribution -This study can serve as a baseline study to be replicated in a future, to monitor rural local residents' attitudes change as the number of tourists 'arrivals increase in the years to come; in connecting rural local residents attitudes with their socio-demographic characteristics to define different segments of rural residents in order to include them into tourism development policy; and for public policy makers of rural areas to be aware of the attitudes of local residents.
\end{abstract}

Keywords rural residents' attitudes, tourism impacts, rural areas, MANOVA

\section{INTRODUCTION}

Local residents are among main stakeholders of tourism development and their attitudes toward tourism development are very important in evaluating the current situation of the destination. Researching rural residents' attitudes can be important factor in tourism development. The role of attitudes is manifested in their strength and the difficulty of analysis lies in the fact that attitudes are fragments of the existing, formed beliefs and as such they hardly change. Understanding the rural residents' attitudes towards tourism impacts could significantly contribute to successful planning and implementation of targeted tourism policy to upgrade the existing and to inspire the future sustainable development of the destination. The local residents' attitudes are many scientists' topic of research who agree in common conclusion that local residents' support for tourism development is affected by the perceived economic, social, cultural and environmental tourism impacts. The main aim of this paper was to research the segment of rural residents' attitudes towards tourism development concerning the economic, sociocultural and environmental tourism impacts and also to research existence of relationships among residents' attitudes related to tourism impacts and their sociodemographic characteristics. 
ToSEE - Tourism in Southern and Eastern Europe, Vol. 5, pp. 521-532, 2019

I. Pavlić, B. Puh, Lj. Mišković: RESIDENTS' ATTITUDES TOWARDS TOURISM IMPACTS IN ...

\section{LITERATURE REVIEW}

The emphasis of scientific research on rural communities started in the middle of the eighties when traditional industries began to fall and tourism emerged as a base for the recovery. Perdue, Long and Allen (1987) were examining the influence of participation in outdoor recreation on the tourism perceptions and attitudes of rural residents from five Colorado communities. The results showed there are no differences in tourism perceptions between participants and nonparticipants in camping and fishing, but they emphasized the limitations in their research such as the measure of outdoor recreation participation and the variation in the response.

In the 1990 Perdue, Long and Allen tested a model of the relationships among rural resident perceptions of tourism impacts, support for additional tourism development, restrictions on tourism development and support for special tourism taxes for additional tourism development connected with specific development policies. The conclusion was that it is necessary to improve the public's perceptions of positive and negative impacts of tourism and the focus shouldn't be just on the economic benefits of tourism. Allen, Hafer, Long and Perdue (1993) did the research based on rural residents' attitudes toward recreation and tourism development using 2x2 ANCOVA, sequential Bonferroni procedure. The results showed that rural residents with low economic activity and low tourism development had high expectations for future tourism development, and the other ones with high economic activity and a high degree of tourism development became aware of benefits from tourism development and their attitudes were more positive toward tourism development. In order to measure the resident attitudes toward tourism development, Lankford and Howard (1993) developed a multiple item tourism impact attitude scales (TIAS). A year later, Lankford (1994) used TIAS to make a comparison between attitudes and support toward tourism development in a hope to be replicated in the future to monitor changes in attitudes.

Mason and Cheyne (2000) were discussing rural resident attitudes towards proposed development in a rural region of New Zeland. By using a questionnaire survey they found out perceived positive impacts such as a provision of a community facility, job creation and the promotion of the chosen area. The negative impacts were a higher number of drunken driving, traffic problems and increased noise considering the gender differences. These findings confirmed the previous claims of the Brougham and Butler (1981), Haralambopolous and Pizam (1996) that communities are made up of different groups and individuals with different attitudes and perceptions related to the perceived tourism impacts. Based on previous work, McGehee and Andereck (2004) used the model developed by Perdue, Long and Allen $(1987,1990)$ to investigate the factors predicting rural residents' support of tourism. The research confirmed the previous findings of Perdue, Long and Allen (1990) that personal characteristic variables didn't predict perception of the impacts of tourism when controlling for perceived benefit from tourism.

Wang and Pfister (2008) used factor analysis to assess the dimensionality of 20 TIAS and 5-point Likert-type response focused not just on the relationships between personal benefits from tourism but also on the nature of benefits associated with tourism. They 
ToSEE - Tourism in Southern and Eastern Europe, Vol. 5, pp. 521-532, 2019

I. Pavlić, B. Puh, Lj. Mišković: RESIDENTS' ATTITUDES TOWARDS TOURISM IMPACTS IN ...

are reserved for recognition of noneconomic perspective of tourism benefits for rural residents where tourism just started with development.

Using the focus group interview, Ezeuduji and Rid (2011) analysed the internal and external environment factors that might influence success or failure of rural tourism development in The Gambia selecting for interviews key stakeholders involved in rural tourism development. The same year, Látková and Vogt (2011) used the one - way ANOVA model which clarifies that residents who personally benefit from tourism and who realize tourism as a development strategy consider tourism more positively and are more supportive of further tourism growth. Abdollahzadeh and Sharifzadeh (2012) in their research used factor analysis and linear structural equation modelling in order to explain the rural resident's perceptions toward the impacts of tourism development and their grouping according to these attitudes. They notice that education, gender, age, income, employment and a high degree of community attachment were the major factors affecting the attitudes of residents. Analysing the community support for tourism development, perceived impacts and community satisfaction, Park, Nunkoo and Yoon (2015) added the effect of social capital. First, they multi-group SEM to analyse the moderating effects of social capital. The study confirmed arguments that social capital is an important factor for better community growth including sustainable tourism development.

Dealing with rural residents' perceptions of the impact of tourism development and the factors that influence the support for sustainable tourism development, Muresan et al. (2016) find out that residents perceive tourism as a development factor and the natural, economic and social-cultural environment, as well as characteristics of the respondents, are the factors that influence the sustainable tourism. Bagri and Kala (2016) also examined the attitude of residents towards tourism impacts but they added the influence of demographic attributes on their attitudes using one - way ANOVA. The results pointed out that residents are aware of tourism impacts in their region related to economic, social and environmental dimension. Boley, McGehee and Hammett (2016) did the research related to importance-performance analysis (IPA) of sustainable tourism initiatives focusing on the resident perspective in three different counties in the Commonwealth of Virginia with different levels of sustainable tourism development. Residents from all three countries put the emphasis on sustainable tourism research, but the differences were in their perceptions of performance. A year later, the structural equation modelling (SEM) was used in order to understand residents' support for tourism development focusing on tourism impacts and community quality of life using eight latent variables ( $\mathrm{Yu}$, Cole and Chancellor, 2018). Sociocultural and environmental benefits contribute to the host community's living experience. After that, there was an investigation of the local residents' perception using choice modelling in rural indigenous destinations in order to recognize which tourism impacts are most anticipated and concerning (Chang et al., 2018). Authors evaluated the influence of socio-culture, economic and environmental impacts on local residents' perceptions using mixed-logistic regression and findings showed that culture-related impacts most improve indigenous residents' tourism development support. Research conducted by Lin, Wang and Yeh (2019) determined that spatial clustering of residents' perceptions of tourism impacts occurred in the specific locations. 
ToSEE - Tourism in Southern and Eastern Europe, Vol. 5, pp. 521-532, 2019

I. Pavlić, B. Puh, Lj. Mišković: RESIDENTS' ATTITUDES TOWARDS TOURISM IMPACTS IN ...

\section{METHODOLOGY}

\subsection{Area of research}

Rural areas of Dubrovnik (Dubrovnik littoral, island Mljet and island Korcula) ${ }^{1}$ are part of the Dubrovnik-Neretva County in the Republic of Croatia. In researched rural areas there are 18780 inhabitants (Dubrovnik littoral 2170, island Mljet 1088 and island Korcula 15522) ${ }^{2}$ (Census of Population, 2011). In Dubrovnik littoral area number of tourists' arrivals has tripled in 2015 in compare to 2005 (30501), while the number of overnights almost doubled in the same period. It has the lowest population density (11 inhabitants per $\mathrm{km}^{2}$ ) and realises $2.62 \%$ of County tourism traffic. Island Korcula has population density of 56 inhabitants per $\mathrm{km}^{2}$. The numbers of tourism arrivals and overnights have decreased from 2005 to 2015 (tourism arrivals from 152637 to 129854 and overnights from 697855 to 756829 ). It realises $12.33 \%$ of County overnight stays and its rural areas (without settlement of Korcula) $7.08 \%$. Island Mljet is very lightly populated with density of 10.5 inhabitants per $\mathrm{km}^{2}$. National park Mljet attracts lots of visitors. From 2005 to 2015 the number of tourism arrivals has increased from 11193 to 19780. The number of overnights stays and accommodation capacities has doubled in the same period. The island Mljet realises $1.5 \%$ of County overnight stays. (Croatia Bureau Statistics, 2016)

\subsection{Sampling, questionnaire design and analytical procedure}

The empirical research was conducted in a period from June 1st 2017 to October 1st 2017 on a stratified sample of 593 local residents living in rural areas of Dubrovnik. Data were collected through a questionnaire consisting of structured questions based on the literature review and previous research in this field (Perdue, Long, \& Allen, 1987; Weaver \& Lawton, 2001; Gursoy et al., 2002; Kuvan \& Akan, 2005; Bujosa \& Roselló, 2007; Amuquandoh, 2010). The first part of questionnaire included statements of positive and negative tourism impacts: economic impacts positive - PECI and negative NECI items, socio-cultural impacts positive - PSCI and negative - NSCI items and environmental impacts positive - PENI and negative - NENI items using a five-point Likert scale ( $1=$ totally disagree, $5=$ totally agree). The second part included statements about socio-demographic: gender, age, level of education, occupation and personal monthly income - PMI and a dichotomous question about job relation to tourism - JRT. The questionnaire was pilot tested and refined before data collection.

Statistical procedures were applied using the SPSS 23. Descriptive statistics were used to analyse the rural residents' profile. The reliability analysis of the scales was tested by evaluating the stability and consistency of each statement. The statements that meet the criterion given by Parasuraman, Zeithaml and Berry (1998) of the item-total correlation of 0.30 or above were used for further analysis. Cronbach's alpha coefficient was also used in testing scale reliability. Peterson (1994) suggested that its value of 0.6 is a

\footnotetext{
1 Research area is the part of the project "Rural educational, cultural and ethnographic tourist attraction" coordinated by Ministry of regional development and EU funds related to operative programme "Competition and Cohesion 2014 - 2020".

2 Since the purpose of this paper was to research rural areas, the settlement of Korcula (2.856 inhabitants) of the island of Korcula has been excluded from analysis.
} 
ToSEE - Tourism in Southern and Eastern Europe, Vol. 5, pp. 521-532, 2019

I. Pavlić, B. Puh, Lj. Mišković: RESIDENTS' ATTITUDES TOWARDS TOURISM IMPACTS IN ...

criterion in use. To analyse the relationship between respondents' attitudes and their socio-demographic characteristics MANOVA was used and to see the differences of respondents' opinion based on their socio-demographic characteristics ANOVA and ttests were applied.

\section{RESULTS}

The results of socio-demographic profile show that female share in the sample was $52.6 \%$ and $47.4 \%$ were male. The age groups were represented as follows: $28.7 \%$ from $18-34,29.8 \%$ from $35-49,21.9 \%$ from $50-64,19.6 \%$ from 65 years old. In researched rural areas as expected, almost one-fifth of residents were 65 or older. The education structure showed that almost $50 \%$ have a secondary school and almost one-fifth is residents without education or with elementary level only. One-third of respondents have a higher level of education. More than one-third are employed and $15.5 \%$ are tradesmen and craftsmen, while $18 \%$ of respondents are retired. The majority of the respondents, $57.1 \%$, had a PMI under 6.001 HRK. Average PMI in Dubrovnik-Neretva County in 2016 was 5.738 HRK (Croatian Bureau of Statistics, 2018).

Table 1 presents the dimensions and reliability analysis of the scale items of different types of positive and negative tourism impacts. Applying reliability analysis, two of the items were deleted (Q13 and Q25). By deleting these statements $\alpha$ has increased. The local residents had the highest average level of agreement with the dimension named as the negative economic impacts (4.26), positive economic impacts (4.12) and negative environmental impacts (4.01).

There is general agreement of the local residents that tourism increases job opportunities (4.53), ensures a better standard of living (4.43) but also that tourism increases litter in an area (4.44). The lowest level of agreement is with the dimensions of negative socioculture impacts, in facts, local residents don't agree that tourism decreases local community safety (2.64), that brings more costs than benefits (2.3) and that tourism jeopardises local authenticity (2.95). The statements with the highest level of agreement (positive economic and negative environmental tourism impacts) have the lowest standard deviation which shows the uniformity of the opinion among rural residents. The highest level of standard deviation has been found in the dimension of negative socioculture impacts which reveals a discrepancy of opinions among rural residents on the issues related to the safety, benefits and authenticity.

Table 1: Dimensions, inferential statistics and reliability analysis of the scale items

\begin{tabular}{|c|c|c|c|}
\hline Statements & $\begin{array}{l}\text { Item total } \\
\text { corr }\end{array}$ & Mean & SD \\
\hline PECI $(\alpha=0.810)$ & & 4.12 & 0.84 \\
\hline Tourism increases job opportunities (Q1) & 0.56 & 4.53 & 0.92 \\
\hline Tourism ensures better standard of living (Q2) & 0.623 & 4.43 & 0.90 \\
\hline Tourism stimulates infrastructure investments (Q3) & 0.658 & 4.08 & 1.19 \\
\hline Tourism gives economic benefits to small crafts (businesses) (Q4) & 0.579 & 4.21 & 1.04 \\
\hline Tourism provides better quality of public services (Q5) & 0.543 & 3.51 & 1.37 \\
\hline Tourism increases foreign and domestic investment (Q6) & 0.513 & 3.95 & 1.07 \\
\hline
\end{tabular}


ToSEE - Tourism in Southern and Eastern Europe, Vol. 5, pp. 521-532, 2019

I. Pavlić, B. Puh, Lj. Mišković: RESIDENTS' ATTITUDES TOWARDS TOURISM IMPACTS IN ...

\begin{tabular}{|c|c|c|c|}
\hline Statements & $\begin{array}{l}\text { Item total } \\
\text { corr }\end{array}$ & Mean & SD \\
\hline NECI $(\alpha=0.713)$ & & 4.26 & 0.84 \\
\hline Tourism increases local products prices (Q7) & 0.555 & 4.32 & 0.93 \\
\hline Tourism increases residents' living costs (Q8) & 0.555 & 4.2 & 0.97 \\
\hline PSCI $(\alpha=0.715 ; \alpha$ if deleted $=0,735)$ & & 3.74 & 0.81 \\
\hline Tourism encourages residents' participation in cultural events (Q9) & 0.566 & 3.7 & 1.27 \\
\hline Tourism affects local residents to visit cultural events (Q10) & 0.511 & 3.41 & 1.36 \\
\hline Tourism motivates local residents to educate (Q11) & 0.416 & 3.76 & 1.13 \\
\hline $\begin{array}{l}\text { Encounters with tourists causes opportunity to learn about different } \\
\text { countries (Q12) }\end{array}$ & 0.373 & 3.89 & 1.13 \\
\hline Tourism stops depopulation of rural areas $(Q 13)$ & 0.211 & 3.67 & 1.22 \\
\hline $\begin{array}{l}\text { Tourism raises more awareness of protection and improvement of } \\
\text { cultural heritage (Q14) }\end{array}$ & 0.456 & 3.85 & 1.03 \\
\hline $\begin{array}{l}\text { Tourism raises more awareness of protection and improvement of } \\
\text { etno-social heritage (Q15) }\end{array}$ & 0.466 & 3.81 & 1.09 \\
\hline $\operatorname{NSCI}(\alpha=0.676)$ & & 2.63 & 1.14 \\
\hline Tourism decreases local community safety (Q16) & 0.516 & 2.64 & 1.44 \\
\hline Tourism brings more costs than benefits (Q17) & 0.506 & 2.3 & 1.39 \\
\hline Tourism jeopardises local authenticity (Q18) & 0.446 & 2.95 & 1.35 \\
\hline PENI $(\alpha=0.851)$ & & 3.73 & $\mathbf{1 . 1 0}$ \\
\hline $\begin{array}{l}\text { Tourism raises more awareness of protection for natural resources } \\
\text { (Q19) }\end{array}$ & 0.742 & 3.74 & 1.15 \\
\hline Tourism influences better environmental protection (Q20) & 0.742 & 3.72 & 1.21 \\
\hline NENI $(\alpha=0.54, \alpha$ if deleted $=0.682)$ & & 3.89 & 0.91 \\
\hline Tourism uses local resources uncontrollably (Q21) & 0.364 & 3.34 & 1.37 \\
\hline Tourism increases the level of sea pollution (Q22) & 0.559 & 3.94 & 1.24 \\
\hline Tourism increases the level of air pollution (Q23) & 0.577 & 3.81 & 1.36 \\
\hline Tourism increases litter in an area (Q24) & 0.395 & 4.44 & 0.82 \\
\hline Tourism cause overcrowding problems for residents $(Q 25)$ & 0.176 & 4.51 & 0.77 \\
\hline
\end{tabular}

Source: Authors' research

Table 2 presents means of dimensions by socio-demographic characteristics analysed by one-way MANOVA. Respondents in higher income categories (above the average income of County) agreed significantly more with the statements about positive economic $(\mathrm{p}=0.000, \mathrm{~F}=5.705)$ and socio-cultural tourism impacts $(\mathrm{p}=0.004, \mathrm{~F}=2.117)$. Also, Bonferroni posthoc test confirmed that there are statistically significant differences between different categories of income level. JRT has shown to have a significant connection with statements about positive and negative socio-cultural impacts and positive environmental tourism impacts. They have higher level of agreement with statements regarding positive socio-cultural impacts $(\mathrm{p}=0.002, \mathrm{~F}=9.659)$, negative sociocultural impacts $(\mathrm{p}=0.039, \mathrm{~F}=4.265)$ and positive environmental impacts $(\mathrm{p}=0,003$, $\mathrm{F}=4.728$ ). Residents between the age of 35 and 49 have shown a higher level of agreement with statements about positive socio-cultural impacts ( $\mathrm{p}=0,005, \mathrm{~F}=4.355)$, and older residents (aged 65+) with a statement regarding negative environmental impacts $(\mathrm{p}=0.002, \mathrm{~F}=4.844)$. Bonferroni posthoc test confirmed the existence of statistically significant differences between old residents and younger ones. Residents with the undergraduate/graduate level of education have shown a higher level of agreement with statements about positive socio-cultural $(\mathrm{p}=0.026, \mathrm{~F}=2.785)$ and negative socio-cultural impacts of tourism $(\mathrm{p}=0.016, \mathrm{~F}=3.079)$. Employment has shown to have a significant connection with statements regarding the negative economic impact of tourism. The MANOVA shows that housekeepers tend to have a higher level of agreement with the statement about the negative economic impacts of tourism ( $\mathrm{p}=0.046, \mathrm{~F}=2.058)$. 
ToSEE - Tourism in Southern and Eastern Europe, Vol. 5, pp. 521-532, 2019

I. Pavlić, B. Puh, Lj. Mišković: RESIDENTS' ATTITUDES TOWARDS TOURISM IMPACTS IN ...

MANOVA results indicate that only gender doesn't have any significant relationship with analysed dimensions.

Table 2: Means of dimensions by socio-demographic characteristics: results of one-way MANOVA

\begin{tabular}{|c|c|c|c|c|c|c|}
\hline & PECI & NECI & PSCI & NSCI & PENI & NENI \\
\hline \multicolumn{7}{|l|}{ Age } \\
\hline $18-34$ & 4.17 & 4.23 & 3.85 & 2.56 & 3.85 & 3.83 \\
\hline $35-49$ & 4.27 & 4.32 & 3.93 & 2.79 & 3.91 & 4.11 \\
\hline $50-64$ & 4.20 & 4.24 & 3.78 & 2.59 & 3.65 & 3.87 \\
\hline \multirow[t]{2}{*}{$65-$} & 4.12 & 4.26 & 3.59 & 2.51 & 3.71 & 4.16 \\
\hline & & & $\begin{array}{l}p=0.005 \\
F=4.355\end{array}$ & & & $\begin{array}{l}p=0.002 \\
F=4.844\end{array}$ \\
\hline \multicolumn{7}{|l|}{ Gender } \\
\hline Female & 4.23 & 4.25 & 3.83 & 2.54 & 3.82 & 3.94 \\
\hline Male & 4.16 & 4.28 & 3.78 & 2.71 & 3.78 & 4.03 \\
\hline \multicolumn{7}{|l|}{ Education } \\
\hline No education & 3.98 & 3.97 & 3.64 & 2.58 & 3.73 & 3.76 \\
\hline El.school & 4.08 & 4.38 & 3.58 & 2.68 & 3.57 & 4.17 \\
\hline Sec. school & 4.27 & 4.29 & 3.86 & 2.54 & 3.84 & 4.03 \\
\hline Underg./ grad. & 4.21 & 4.26 & 3.87 & 2.84 & 3.83 & 3.94 \\
\hline \multirow[t]{2}{*}{ Postgraduate } & 3.94 & 4.36 & 3.56 & 2.06 & 3.89 & 3.78 \\
\hline & & & $\begin{array}{l}p=0.026 \\
F=2.785\end{array}$ & $\begin{array}{l}p=0.016 \\
F=3.079\end{array}$ & & \\
\hline \multicolumn{7}{|l|}{ Occupation } \\
\hline Employed & 4.25 & 4.33 & 3.89 & 2.6 & 3.82 & 4.06 \\
\hline $\begin{array}{l}\text { Tradesman and } \\
\text { craftsman }\end{array}$ & 4.16 & 4.29 & 3.85 & 2.71 & 3.97 & 3.85 \\
\hline Unemployed & 4.26 & 4.13 & 3.82 & 2.95 & 3.73 & 3.88 \\
\hline Retired & 3.92 & 4.06 & 3.64 & 2.55 & 3.70 & 4.06 \\
\hline Student & 4.26 & 4.20 & 3.74 & 2.42 & 3.64 & 3.74 \\
\hline \multirow[t]{2}{*}{ Housekeeper } & 4.32 & 4.55 & 3.68 & 2.32 & 3.58 & 4.19 \\
\hline & & $\begin{array}{c}p=0.0 \\
F=2.058\end{array}$ & & & & \\
\hline \multicolumn{7}{|l|}{ PMI } \\
\hline without income & 4.00 & 4.10 & 3.82 & 2.64 & 3.54 & 3.79 \\
\hline-2000 & 3.99 & 4.27 & 3.64 & 2.81 & 3.72 & 3.91 \\
\hline $2001-4000$ & 3.83 & 4.12 & 3.58 & 2.69 & 3.48 & 4.06 \\
\hline $4001-6000$ & 4.25 & 4.32 & 3.86 & 2.45 & 3.88 & 3.98 \\
\hline $6001-8000$ & 4.35 & 4.36 & 3.83 & 2.72 & 3.86 & 4.17 \\
\hline $8001-10000$ & 4.51 & 4.46 & 3.96 & 2.78 & 4.01 & 4.18 \\
\hline $10001-12000$ & 4.23 & 4.10 & 3.89 & 2.46 & 3.91 & 3.63 \\
\hline \multirow[t]{2}{*}{$12000-$} & 4.35 & 4.13 & 3.96 & 2.47 & 3.92 & 3.73 \\
\hline & $\begin{array}{l}p=0.000 \\
F=5.705\end{array}$ & & $\begin{array}{l}p=0.004 \\
F=2.117\end{array}$ & & & \\
\hline \multicolumn{7}{|l|}{ JRT } \\
\hline Yes & 4.21 & 4.21 & 3.91 & 2.72 & 3.90 & 3.93 \\
\hline \multirow[t]{2}{*}{ No } & 4.18 & 4.32 & 3.70 & 2.53 & 3.70 & 4.04 \\
\hline & & & $\begin{array}{l}p=0.002 \\
F=9.659\end{array}$ & $\begin{array}{l}p=0.039 \\
F=4.265\end{array}$ & $\begin{array}{l}p=0.003 \\
F=4.728\end{array}$ & \\
\hline
\end{tabular}

Source: Authors' research 
ToSEE - Tourism in Southern and Eastern Europe, Vol. 5, pp. 521-532, 2019

I. Pavlić, B. Puh, Lj. Mišković: RESIDENTS' ATTITUDES TOWARDS TOURISM IMPACTS IN ...

For the advanced analysis of the data, t-tests was used for the JRT variable; and ANOVA for the variables age, education, employment and PMI.

Local residents who have JRT had a higher level of agreement with the statements Q6 and Q12. Also, they had the lowest level of agreement with the statement Q17. This can be explained with the fact that they work in the tourism industry and have benefits (monthly income). Most of the statements that are statistically significant are related to positive and negative socio-culture impacts.

Table 3: T-test results

\begin{tabular}{|c|c|c|c|c|}
\hline \multirow{2}{*}{ Impacts statements } & \multicolumn{4}{|c|}{ JRT } \\
\cline { 2 - 5 } & Yes & No & $\mathbf{p}$ & t-values \\
\hline Q3 & 4.08 & 3.83 & 0.023 & 2.824 \\
\hline Q9 & 3.90 & 3.51 & 0.01 & 3.789 \\
\hline Q12 & 4.05 & 3.73 & 0.024 & 3.515 \\
\hline Q14 & 3.91 & 3.79 & 0.045 & 1.356 \\
\hline Q16 & 2.67 & 2.6 & 0.000 & 0.635 \\
\hline Q17 & 2.40 & 2.19 & 0.000 & 1.848 \\
\hline Q18 & 3.06 & 2.84 & 0.001 & 1.94 \\
\hline & 3.77 & 4.12 & 0.034 & -3.439 \\
\hline
\end{tabular}

Source: Authors' research

The results of the one-way ANOVA test (Table 4) show that most of the sociodemographic variables (age, education, occupation and income level) are associated with certain statements about positive and negative tourism impacts. Regarding the variable "Age" relation between local residents' attitudes and positive and negative socio-cultural tourism impacts and negative environmental tourism impacts, has been determined. Namely, younger and middle age residents in comparison to older ones (65+) have more positive attitudes about socio-cultural tourism impacts Q9, Q10 and Q16. On the other side older residents are more environmentally aware since they agree more with the statements that tourism increases the level of the sea and air pollution. Concerning the level of education, local residents perceive just one of six statements of the positive economic impacts, half of the positive socio-culture statements, most of the negative socio-culture impacts and half of the negative environmental statements. Local residents with higher level of education in comparison to those with no education and with elementary school have higher level of agreement with the statements Q3, Q9, Q12, Q15, Q16, Q17 and Q23. Generally concluded it can be said that rural residents with higher level of education perceive more positive but also negative tourism impacts than rural residents without or with a basic level of education. Considering the variable Occupation, local residents perceive one-third of positive economic statements, half of the negative economic statements and one-third negative socio-culture statements. Students have the highest level of agreement with the statements Q1 and Q2 while the lowest level is found among retired and housekeepers. Housekeepers, retired and unemployed residents agree with the statement Q7. On the other side, students have the lowest level of agreement with that statement. With the statement Q17 the highest level of agreement housekeepers, retired and unemployed and the lowest level of agreement is within students' population. These results can be explained with the fact that housekeepers, retired and unemployed residents have the lower level of income and education so they are more sensitive to the prices changes and therefore they think that generally, tourism causes more 
ToSEE - Tourism in Southern and Eastern Europe, Vol. 5, pp. 521-532, 2019

I. Pavlić, B. Puh, Lj. Mišković: RESIDENTS' ATTITUDES TOWARDS TOURISM IMPACTS IN ...

disadvantages for them than advantages. On the other side, students see tourism as a possibility for the future employment and for the development of the area. Regarding income level, ANOVA results indicate the existence of higher level of agreement with certain statements of positive economic impacts Q1, Q2, Q3, Q4, Q5 and positive socioculture impacts Q9, Q10 for those residents with the above average PMI. The $\chi^{2}$ test shows that there is a statistically significant relationship between the level of PMI and JRT ( $\mathrm{P}=0,017)$. Residents with above-average PMI tend to be more JRT so they perceive it as a source of economic benefits and therefore have a higher level of agreement with the statements of positive economic tourism impacts.

Table 4: ANOVA results

\begin{tabular}{|c|c|c|c|c|c|c|c|c|c|c|}
\hline Age & $18-34$ & $35-49$ & $50-64$ & $65-$ & $F$ & $p$ & & & & \\
\hline Q9 & 3.81 & 3.89 & 3.72 & 3.25 & 6.681 & 0.000 & & & & \\
\hline Q10 & 3.43 & 3.56 & 3.49 & 3.07 & 3.405 & 0.017 & & & & \\
\hline Q16 & 2.56 & 2.85 & 2.77 & 2.26 & 4.559 & 0.004 & & & & \\
\hline Q22 & 3.71 & 4.12 & 3.82 & 4.16 & 4.963 & 0.002 & & & & \\
\hline Q23 & 3.62 & 3.95 & 3.70 & 4.00 & 2.829 & 0.038 & & & & \\
\hline $\begin{array}{l}\text { Educa- } \\
\text { tion }\end{array}$ & $\begin{array}{c}\text { No } \\
\text { edu. }\end{array}$ & $\begin{array}{c}\text { El. } \\
\text { sch. }\end{array}$ & $\begin{array}{l}\text { Sec. } \\
\text { sch. }\end{array}$ & $\begin{array}{l}\text { Und/ } \\
\text { Grad. }\end{array}$ & $\begin{array}{l}\text { Post- } \\
\text { grad. }\end{array}$ & $\boldsymbol{F}$ & $p$ & & & \\
\hline Q3 & 3.71 & 4.00 & 4.16 & 4.17 & 4.44 & 3.321 & 0.011 & & & \\
\hline Q9 & 3.47 & 3.27 & 3.77 & 3.81 & 3.83 & 2.762 & 0.027 & & & \\
\hline Q12 & 3.55 & 3.5 & 3.91 & 4.04 & 4.44 & 5.032 & 0.001 & & & \\
\hline Q15 & 3.67 & 3.58 & 3.69 & 3.87 & 3.87 & 2.947 & 0.02 & & & \\
\hline Q16 & 2.53 & 2.48 & 2.60 & 2.87 & 2.78 & 3.047 & 0.017 & & & \\
\hline Q17 & 2.24 & 2.14 & 2.33 & 2.58 & 2.72 & 3.72 & 0.005 & & & \\
\hline Q23 & 3.56 & 4.13 & 3.87 & 3.74 & 3.67 & 2.577 & 0.037 & & & \\
\hline $\begin{array}{l}\text { Occu- } \\
\text { pation }\end{array}$ & $\begin{array}{c}\text { Emp- } \\
\text { loy. }\end{array}$ & $\begin{array}{c}\text { Trad./ } \\
\text { craf. }\end{array}$ & $\begin{array}{l}\text { Un- } \\
\text { empl. }\end{array}$ & $\begin{array}{c}\text { Reti- } \\
\text { red }\end{array}$ & $\begin{array}{l}\text { Stu- } \\
\text { dent }\end{array}$ & $\begin{array}{c}\text { Hou- } \\
\text { se- } \\
\text { keeper }\end{array}$ & $\boldsymbol{F}$ & $p$ & & \\
\hline Q1 & 4.33 & 4.26 & 4.33 & 3.32 & 4.58 & 3.52 & 2.782 & 0.007 & & \\
\hline Q2 & 4.12 & 4.09 & 4.07 & 3.62 & 4.16 & 3.84 & 2.738 & 0.008 & & \\
\hline Q7 & 4.29 & 4.32 & 4.41 & 4.49 & 4.26 & 4.55 & 2.331 & 0.024 & & \\
\hline Q17 & 2.40 & 2.19 & 2.63 & 2.43 & 1.98 & 2.68 & 2.438 & 0.018 & & \\
\hline $\begin{array}{l}\text { Income } \\
\text { level }\end{array}$ & $\begin{array}{l}\text { No } \\
\text { inc. }\end{array}$ & -2000 & $\begin{array}{l}2001- \\
4.000 \\
\end{array}$ & $\begin{array}{l}4001- \\
6000 \\
\end{array}$ & $\begin{array}{l}6001- \\
8000\end{array}$ & $\begin{array}{l}8001- \\
10000 \\
\end{array}$ & $\begin{array}{l}\text { 10001- } \\
12000\end{array}$ & 12000- & $\mathbf{F}$ & $\mathbf{p}$ \\
\hline Q1 & 4.23 & 4.42 & 4.33 & 4.55 & 4.66 & 4.79 & 4.66 & 4.53 & 2.536 & 0.014 \\
\hline Q2 & 4.10 & 4.28 & 4.2 & 4.49 & 4.55 & 4.63 & 4.43 & 4.55 & 2.815 & 0.007 \\
\hline Q3 & 3.44 & 3.84 & 3.63 & 4.20 & 4.29 & 4.49 & 4.27 & 4.37 & 6.377 & 0 \\
\hline Q4 & 4.00 & 4.00 & 3.75 & 4.27 & 4.38 & 4.54 & 4.43 & 4.29 & 4.916 & 0 \\
\hline Q5 & 3.31 & 3.24 & 3.08 & 3.61 & 3.62 & 3.97 & 3.70 & 3.75 & 3.082 & 0.003 \\
\hline Q9 & 3.87 & 3.31 & 3.29 & 3.76 & 3.9 & 3.9 & 3.84 & 4.00 & 3.496 & 0.001 \\
\hline Q10 & 3.44 & 3.19 & 3.00 & 3.33 & 3.77 & 3.62 & 3.49 & 3.59 & 2.876 & 0.006 \\
\hline
\end{tabular}

Source: Authors' research 
ToSEE - Tourism in Southern and Eastern Europe, Vol. 5, pp. 521-532, 2019

I. Pavlić, B. Puh, Lj. Mišković: RESIDENTS' ATTITUDES TOWARDS TOURISM IMPACTS IN ...

\section{CONCLUSION}

Local residents regardless of living in rural areas perceive positive but also negative tourism impacts as local residents in urban areas. This paper confirms that there are certain differences in attitudes of local residents towards various dimensions of tourism impacts considering their socio-demographic characteristics and JRT. The differences appear to exist in relation to age, education, occupation, PMI and JRT. The local residents had the highest average level of agreement with the dimension named as the negative economic impacts, positive economic impacts and negative environmental impacts and the lowest level of agreement with the dimensions of negative socio-culture impacts. The results show that the highest level of impact on residents 'attitudes is variable JRT which affects attitudes about positive and negative socio-cultural impacts and positive environmental tourism impacts. PMI affects attitudes about positive economic and positive socio-cultural. Education influences attitudes regarding positive and negative socio-cultural impacts and variable age positive socio-cultural and negative environmental tourism impacts respectively. Occupation, on the other hand, has a connection only with attitudes about negative economic impacts, while gender as a variable does not have any significant connections with mentioned dimensions.

Most of the statements that are statistically significant in t-test are related to positive and negative socio-culture impacts. Rural local residents see the potential for growth and investment in tourism development as well as in the whole rural area. Besides, they see an opportunity in including in cultural life and events to present their history and save the authenticity of the area. The results of the one-way ANOVA test show that most of the socio-demographic variables (age, education, occupation and income level) are associated with certain statements about positive and negative tourism impacts. However the paper should be seen in the light of its limitations. Rural areas included in this paper are the part of a bigger project which anticipated researched rural areas and excluded eastern rural areas of the County. Further research should include similar analysis in the eastern part of the County and in other rural areas of Croatia. Besides, segmentation of rural residents is needed for adjustment of different educational programme about sustainable tourism development possibilities with the aim of ending depopulation of the rural areas. In that way, local authenticity will be preserved in rural areas and rural residents will be in the position to include their products in tourism offering.

\section{REFERENCES}

Abdollahzadeh, G. and Sharifzadeh, A. (2012), "Rural resident's Perceptions Toward Tourism Development: a Study from Iran”, International Journal of Tourism Research, Vol. 16, No. 2, https://doi.org/10.1002/jtr.1906

Allen, L.R., et al. (1993), "Rural Residents' Attitudes Toward Recreation and Tourism Development"', Journal of Travel and Research, Vol. 31, No. 4, pp. 27-33 https://doi.org/10.1177/004728759303100405

Amuquandoh, F.E. (2010), "Residents' Perceptions of the Environmental Impacts of Tourism in the Lake Bosomtwe Basin, Ghana”, Journal of Sustainable Tourism, Vol. 18, No. 2, pp. 223-238. https://doi.org/10.1080/09669580903298531

Bagri, S.C. and Kala, D. (2016), "Residents' Attitudes toward Tourism Development and Impacts in KotiKansar, Indroli, Pattyur Tourism Circuit of Uttarakhand State, India", Revista de Turismo y Patrimonio Cultural, Vol. 14, No. 1, pp. 23-39 https://doi.org/10.25145/j.pasos.2016.14.002 
ToSEE - Tourism in Southern and Eastern Europe, Vol. 5, pp. 521-532, 2019

I. Pavlić, B. Puh, Lj. Mišković: RESIDENTS' ATTITUDES TOWARDS TOURISM IMPACTS IN ...

Boley, B.B., McGehee, N.G. and Hammet, A.L.T. (2016), "Importance-Performance Analysis (IPA) of Sustainable Tourism Initiatives: The resident perspective”, Tourism Management, Vol. 58, pp. 6677 https://doi.org/10.1016/j.tourman.2016.10.002

Bujosa, A., and Roselló, J. (2007), "Modelling environmental attitudes toward tourism", Tourism Management, 28, pp. 688-695 doi: 10.1016/j.tourman.2006.04.004

Chang, K.G. et al. (2018), "The Impacts of Tourism Development in Rural Indigenous Destinations: An Investigation of the Local Residents' Perception Using Choice Modeling”, Sustainability, Vol. 10, No. 12, DOI: $10.3390 / \mathrm{su} 10124766$

Exchange rate list, Croatian National Bank, https://www.hnb.hr/temeljne-funkcije/monetarna-politika/tecajnalista/tecajna-lista February 15th, 2019

Ezeuduji, I.E. and Rid, W. (2011), "Rural Tourism Offer and Local Community Participation in the Gambia", Tourismos: An International Multidisciplinary Journal of Tourism, Vol. 6, No. 2, pp. 187-211.

First Release, Tourists' arrivals and overnights in 2015, No 4.3.2., Croatian Bureau of Statistics, Zagreb, 2016

Gursoy, D., Jurowski, C., and Uysal, M. (2002), "Residents Attitudes A Structural Modelling Approach", Annals of Tourism Research, Vol. 29, No. 1, pp. 79-105 https://doi.org/10.1016/S0160-7383(01)00028-7

Haralambopoulos, N. and Pizam, A. (1996), "Perceived Impacts of Tourism The Case of Samos", Annals of Tourism Research, Vol. 23, No. 3, pp. 503-526 https://doi.org/10.1016/0160-7383(95)00075-5

Kuvan, Y., and Akan, P. (2005), "Residents' attitudes toward general and forest-related impacts of tourism: the case of Belek, Anatalya", Tourism Management, 26, pp. 691-706 DOI: 10.1016/j.tourman.2004.02.019

Lankford, S.V. (1994), "Attitudes and Perceptions Toward Tourism and Rural Regional Development", Journal of Travel Research, Vol. 32, No. 3. pp. 35-43 https://doi.org/10.1177/004728759403200306

Lankford, S.V. and Howard, D.R. (1993), "Developing a Tourism Impact Attitude Scale", Annals of Tourism Research, Vol. 21, No. 1, pp. 121-139 https://doi.org/10.1016/0160-7383(94)90008-6

Látková, P. And Vogt, C.A. (2011), "Residents' Attitudes toward Existing and Future Tourism Development in Rural Communities", Journal of Travel Research, Vol. 51, No. 1. pp. 50-67 https://doi.org/10.1177/0047287510394193

Lin, C.H., Wang, W.C. and Yeh, Y.E. (2019), "Spatial Distributive Differences in Residents' Perceptions of Tourism Impacts in Support for Sustainable Tourism Development - Lu-Kang Destination Case", Environments, Vol. 6, No. 1 https://doi.org/10.3390/environments6010008

Mason, P. And Cheyne, J. (2000), "Residents' Attitudes to Proposed Tourism Development", Annals of Tourism Research, Vol. 27, No. 2, pp. 391-411 https://doi.org/10.1016/S0160-7383(99)00084-5

McGehee, N.G. and Andereck, K.L. (2004), “Factors Predicting Rural Residents' Support of Tourism”, Journal of Travel Research, Vol. 43, No. 2, pp. 131-140 https://doi.org/10.1177/0047287504268234

Methodological guidelines 67, The Model for the Differentiation of Urban, Rural and Semi-Urban Settlements in the Republic of Croatia, Croatian Bureau of Statistics, Zagreb, 2011.

Muresan, I.C. et al. (2016), "Local Residents' Attitude Toward Sustainable Rural Tourism Development", Sustainability, Vol. 8, No. 1., pp. 1-14.

Parasuraman, A., Zeithaml, V. and Berry, L. L. (1988), "SERVQUAL: A Multiple-Item Scale for Measuring Customer Perceptions of Service Quality", Journal of Retailing, Spring, pp. 12-40.

Park, D.B., Nunkoo, R. and Yoon, Y.S. (2015), "Rural Residents' Attitudes to Tourism and the Moderating Effects of Social Capital", Tourism Geographies, Vol. 17, No. 1, pp. 112-133 https://doi.org/10.1080/14616688.2014.959993

Perdue, R. R., Long, P. T., and Allen, L. (1987), "Rural resident tourism perceptions and attitudes", Annals of Tourism Research, Vol. 14, No. 3, pp. 420-429 https://doi.org/10.1016/0160-7383(87)90112-5

Perdue, R.R., Long, P.T. and Allen, L. (1990), "Resident Support for Tourism Development", Annals of Tourism Research, Vol. 17, No. 4. pp. 586-599 https://doi.org/10.1016/0160-7383(90)90029-Q

Peterson, R.A. (1994), “A meta-analysis of Cronbach's coefficient alpha”, Journal of Consumer Research, Vol. 21, No. 2, pp. 381-392 https://doi.org/10.1086/209405

Statistical reports 1441, Census of Population, Households and Dwellings 2011, First results by Settlements, Zagreb, Croatian Bureau of Statistics, 2011.

Statistical reports 1625, Employment and wages 2017, Croatian Bureau of Statistics, Zagreb, 2018

Wang, Y.A. and Pfister, R.E. (2008), "Residents' Attitudes Toward Tourism and Perceived Personal Benefits in a Rural Community", Journal of Travel Research, Vol. 47, No. 1, pp. 84-93 DOI: $10.1177 / 0047287507312402$

Weaver, D. B., and Lawton, L. J. (2001), "Resident Perception in the Urban-Rural Fringe", Annals of Tourism Research, Vol. 28, No. 2, pp. 439-458 doi: 10.1016/S0160-7383(00)00052-9 
ToSEE - Tourism in Southern and Eastern Europe, Vol. 5, pp. 521-532, 2019

I. Pavlić, B. Puh, Lj. Mišković: RESIDENTS' ATTITUDES TOWARDS TOURISM IMPACTS IN ...

Yu, C.P., Cole, S.T. and Chancellor, C. (2018), "Resident Support for Tourism Development in Rural Midwestern (USA) Communities: Perceived Tourism Impacts and Community Quality of Life Perspective", Sustainability, Vol. 10, No. 3, https://doi.org/10.3390/su10030802

Ivana Pavlić, $\mathrm{PhD}$, Associate Professor

University of Dubrovnik

Department of Economics and Business

Lapadska obala 7, 20000 Dubrovnik, Croatia

Phone: +385-20-445929

E-mail: ipavlic@unidu.hr

Barbara Puh, PhD, Assistant Professor

University of Dubrovnik

Department of Economics and Business

Lapadska obala 7, 20000 Dubrovnik, Croatia

Phone: +385-20-445923

E-mail: barbara.puh@unidu.hr

Ljubica Mišković, mag. oec, Assistant

University of Dubrovnik

Department of Economics and Business

Lapadska obala 7, 20000 Dubrovnik, Croatia

Phone: +385-20-445934

E-mail: ljubica.miskovic@unidu.hr 